\title{
Salt content in canteen and fast food meals in Denmark
}

\author{
Lone Banke Rasmussen'*, Anne Dahl Lassen', Kirsten Hansen², \\ Pia Knuthsen ${ }^{3}$, Erling Saxholt' and Sisse Fagt'
}

'Department of Nutrition, National Food Institute, Technical University of Denmark, Søborg, Denmark; ${ }^{2}$ Region North Laboratory, Danish Veterinary and Food Administration, Aarhus, Denmark; ${ }^{3}$ Department of Food Chemistry, National Food Institute, Technical University of Denmark, Søborg, Denmark

\section{Abstract}

Background: A high salt $(=\mathrm{NaCl})$ intake is associated with high blood pressure, and knowledge of salt content in food and meals is important, if the salt intake has to be decreased in the general population.

Objective: To determine the salt content in worksite canteen meals and fast food.

Design: For the first part of this study, 180 canteen meals were collected from a total of 15 worksites with inhouse catering facilities. Duplicate portions of a lunch meal were collected from 12 randomly selected employees at each canteen on two non-consecutive days. For the second part of the study, a total of 250 fast food samples were collected from 52 retail places representing both city (Aarhus) and provincial towns. The canteen meals and fast food samples were analyzed for chloride by potentiometric titration with silver nitrate solution, and the salt content was estimated.

Results: The salt content in lunch meals in worksite canteens were $3.8 \pm 1.8 \mathrm{~g}$ per meal and $14.7 \pm 5.1 \mathrm{~g}$ per 10 MJ for men $(n=109)$, and $2.8 \pm 1.2 \mathrm{~g}$ per meal and $14.4 \pm 6.2 \mathrm{~g}$ per $10 \mathrm{MJ}$ for women $(n=71)$. Salt content in fast food ranged from $11.8 \pm 2.5 \mathrm{~g}$ per $10 \mathrm{MJ}$ (burgers) to $16.3 \pm 4.4 \mathrm{~g}$ per $10 \mathrm{MJ}$ (sausages) with a mean content of $13.8 \pm 3.8 \mathrm{~g}$ per $10 \mathrm{MJ}$.

Conclusion: Salt content in both fast food and in worksite canteen meals is high and should be decreased.

Keywords: catering; salt intake; meals; canteen meals; burgers; pizzas; sausages; salt

Received: 18 September 2009; Revised: 28 January 20 I0; Accepted: 8 February 20 I0; Published: 16 March 2010

$\mathrm{A}$ n association between salt $(=\mathrm{NaCl})$ intake and blood pressure has been reported in many epidemiological studies (1). Furthermore, some recent studies have shown that high salt intake is independently associated with increased risk of cardiovascular disease (2). Besides this, high salt intake may be a risk factor for other diseases like stomach cancer and have a negative effect on calcium and bone mineral metabolism.

The intake of salt in many countries is far above the recommended intake. In most European countries the salt intake ranges from 9 to $12 \mathrm{~g}$ per day in men and 7 to 9 g per day in women (3). The recommended intake differs from country to country, but most countries recommend 5-6 g per day at least as a long-term goal. In Denmark the recommended intake is $6 \mathrm{~g}$ per day for women and $7 \mathrm{~g}$ per day for men, with the long-term goal of 5-6 g per day (4).
The growing interest in the role of salt intake for disease prevention increases the need for strategies to reduce the salt intake in a population. It is necessary to know the important sources of salt in the diet. A recent Danish study showed that the intake of household salt is very low and most salt are derived from other sources (5).

The catering industry has a great responsibility to provide nutritious food to the consumers, but also in influencing perceived norms regarding eating behavior (i.e. change preference for salty food). Moderate reduction of dietary salt has been demonstrated to decrease preference for salty food (6).

Like in many other countries the intake of fast food meals has increased in Denmark since the 1970s (7). Salt intake has been found to be higher among women classified as having a fast food eating pattern compared with women with other eating patterns (8).

The aim of this study was to determine the salt content in fast food and worksite canteen meals. 


\section{Methods}

\section{Worksite canteen meals}

The study sample consisted of 180 canteen meals as described earlier (9). The recruitment took place in two steps. A total of 23 worksites with in-house catering facilities representing both city (Aarhus) and smaller towns all situated in Jutland, were asked to participate in a survey describing the menus and serving system in the canteen. The worksites were selected randomly from a central national register. Worksite information was obtained on number of meals served, occupation (physically exacting to sedentary work), sex distribution, and canteen serving system to make sure that the final distribution would match the country as a whole. Two worksites refused to participate because of lack of time and one worksite was excluded to match the desired average distribution. A total of 20 worksites agreed to participate. Afterwards, the 20 worksites were asked to participate in the present study focusing on individual canteen food intake. Five of the 20 worksites refused to participate with the following reasons: lack of time (three worksites) or concerns of the employees' reaction to the study (two worksites). Eight of the worksites that agreed to participate mainly served buffet style and seven of the worksites served à la carte line. Data collection took place between February and November 2004.

The double portion technique with subsequent chemical analysis was used to quantify actual lunch intakes at the worksite canteens. Duplicate portions were collected from a total of 12 customers at each canteen on two different days (six samples per day). Employees were asked at random to participate in the study, and in average two persons at each canteen rejected to participate. Identical duplicate portions of the employees' selected food were collected by laboratory technicians. All items of the meal including bread, spread, fruit, dessert, etc. were sampled. However, beverages were not included in the analysis.

After the employees finished eating their lunch, they were asked to return the plates to the technicians in order to record/subtract plate waste. Salt added at the table was not included. The duplicate portions were individually mixed and homogenized in a Grindomix type GM200 (Retch).

\section{Fast food}

Fast food was defined as food that can be eaten without the use of knife and fork. Before the data collection was carried out, a survey was performed to study the consumption of various kinds of fast food in Denmark, and the result of this survey was used to plan the data collection to be representative for the consumption of fast food in Denmark.

Fast food samples were collected from 52 retail places representing both city (Aarhus) and provincial towns, including pizzerias, major burger chain restaurants, outlets selling fast food, hot-dog stands, kiosks, and petrol stations. A total of 250 samples were collected in the period February 2004 to June 2005. The samples were subdivided into seven groups of fast food and further divided into 45 different subgroups. The seven main groups were: burgers, sandwiches, pitas, durum rolls, sausages, grilled meals, and pizzas.

Three items of each of the 250 fast foods were collected, weighed separately, then mixed and homogenized in a Grindomixer (Retsch) and kept in plastic bags at $-18^{\circ} \mathrm{C}$ until analysis. Moreover, one sample of each fast food was separated and all components were weighted.

\section{Analyses}

Chloride content was determined and salt content was estimated by multiplying with 1.648 . The chloride ion concentration was determined by potentiometric titration with silver nitrate solution, and salt content was estimated from the chloride content.

Analyses of the content of protein, fat, and ash were performed according to procedures given by the Nordic Committee on Food Analysis (10-12). Dry matter content was determined by drying in a vacuum oven at $70^{\circ} \mathrm{C}$ to constant weight. Carbohydrate and energy content were calculated from contents of dry matter, protein, fat, and ash (13).

\section{Calculations}

Canteen meals were categorized into four groups: (1) hot meals, (2) sandwiches (mainly open sandwiches), (3) salad, or (4) a combination of hot meals/sandwiches and salad/fruit/snack vegetables.

As some fast food is eaten as combo menus with a combination of e.g. sausages and bread, ketchup, mustard, burger in combination with chips, etc., the salt content of typical menus was calculated. Condiments were not analyzed. The calculations were made by using food composition table values (14) for the salt content and the analyzed value for the main part of the meal. The weight of the condiments used in the calculation was determined as described above. It was not possible to give standard deviations for the salt contents in meals as these are calculated values.

\section{Statistics}

Results are given in mean \pm SD. Comparisons of salt content in meals between men and women, and between 
Table 1. Salt intake in meals eaten in worksite canteens $($ mean \pm SD)

\begin{tabular}{|c|c|c|c|c|}
\hline & Men $(n=109)$ & Women $(n=7 \mathrm{I})$ & All $(n=180)$ & $p$-value* \\
\hline Salt intake (g per meal) & $3.8 \pm 1.8$ & $2.8 \pm 1.2$ & $3.4 \pm 1.6$ & $<0.001$ \\
\hline Salt intake (g per $100 \mathrm{~g}$ ) & $1.0 \pm 0.3$ & $0.9 \pm 0.4$ & $1.0 \pm 0.4$ & 0.044 \\
\hline Salt intake (g per $10 \mathrm{MJ})$ & $14.7 \pm 5.1$ & $14.4 \pm 6.2$ & $14.6 \pm 5.5$ & 0.498 \\
\hline
\end{tabular}

*Difference between genders.

Table 2. Salt intake from various meal options eaten in worksite canteens (mean \pm SD)

\begin{tabular}{|c|c|c|c|c|}
\hline & Hot meals $(n=42)$ & Sandwiches $(n=32)$ & Salad $(n=20)$ & Combination $(n=86)$ \\
\hline Salt intake (g per meal) & $4.3 \pm 1.9$ & $3.1 \pm 1.2$ & $1.9 \pm 0.9 *$ & $3.4 \pm 1.5$ \\
\hline Salt intake (g per $100 \mathrm{~g})$ & $\mathrm{I} . \mathrm{I} \pm 0.4$ & $1.2 \pm 0.3$ & $0.6 \pm 0.3 *$ & $0.9 \pm 0.3$ \\
\hline Salt intake (g per $10 \mathrm{MJ})$ & $16.1 \pm 6.4$ & $13.0 \pm 3.8$ & $10.8 \pm 4.8^{*}$ & $15.3 \pm 5.4$ \\
\hline
\end{tabular}

$*_{p}<0.05$ compared with the other meal options.

different kinds of meals were done using students $t$-test. Data processing was done with SPSS version 14.0 (Chicago, IL, USA).

\section{Results}

The salt content in lunch meals in worksite canteens is shown in Table 1. The intake is higher in men compared with women when given as gram per meal, but there was no gender difference per energy unit.

Of the 180 meals, $109(61 \%)$ had a salt content at or below $1.0 \mathrm{~g}$ per $100 \mathrm{~g}$. Eleven $(6 \%)$ of the meals had a salt content at or below $7 \mathrm{~g}$ per $10 \mathrm{MJ}$. Five $(3 \%)$ of the meals had a salt content equal to or more than the recommended daily salt intake of $7 \mathrm{~g}$.

The salt content in various canteen meals is given in Table 2, per $100 \mathrm{~g}$, per portion, and per $10 \mathrm{MJ}$. The salt content in salad was significantly lower than the salt content in other meal types when expressed in all three ways, but no significant differences were found between salt content in the other meal types with mean salt content ranging from 13.0 to $16.1 \mathrm{~g}$ per $10 \mathrm{MJ}$.

The salt content in various groups of fast food is given in Table 3. Table 4 shows the salt content in selected subgroups of fast food. In only $17(7 \%)$ of the fast foods was the salt content below $7 \mathrm{~g}$ per $10 \mathrm{MJ}$. Mean content per $10 \mathrm{MJ}$ ranged from 12.2 to 16.1 . Salt content in some commonly eaten complete fast food meals were estimated to range from 4.4 to $9.1 \mathrm{~g}$ per meal or 7.7 to $21 \mathrm{~g}$ per 10 MJ (Table 5).

\section{Discussion}

This study shows that the salt content in both worksite canteen meals and fast food is high compared to the recommended daily intake. When expressed as g salt per
$10 \mathrm{MJ}$, the mean salt content in canteen meals was generally even higher than the salt content in fast food.

The present study shows that a single canteen meal may provide more than half of the daily recommended amount of salt and that some meals even contain more than the daily recommended amount. Although only few studies have assessed salt content in canteen meals, a high content of salt seems to be a general finding. A study from France (15) found a mean content of $3.4 \mathrm{~g}$ salt in lunch meals from various catering establishments. Likewise, a recent Belgian study found a salt content of $3.1 \mathrm{~g}$ in lunch meals consumed at Ghent University (16). Both these results were similar to ours. Salt added at the table was not included in any of the studies.

If the mean amount of salt in the lunch meal is extrapolated to a daily intake, it would be $14.6 \mathrm{~g}$ per day for a person consuming $10 \mathrm{MJ}$. This is a very high value compared to the recommended long-term goal of

Table 3. Salt content in various kinds of fast food (mean \pm SD)

\begin{tabular}{lcc}
\hline & $\begin{array}{c}\text { Salt content } \\
\text { (g per I00 g) }\end{array}$ & $\begin{array}{c}\text { Salt content per I0 MJ } \\
\text { (g per I0 MJ) }\end{array}$ \\
\hline Burgers $(n=36)$ & $1.15 \pm 0.27$ & $11.8 \pm 2.5$ \\
Pitas $(n=20)$ & $0.86 \pm 0.24$ & $12.2 \pm 3.4$ \\
Pizzas $(n=33)$ & $1.71 \pm 0.53$ & $15.0 \pm 4.8$ \\
Sausages $(n=28)$ & $2.02 \pm 0.58$ & $16.3 \pm 4.4$ \\
Sandwiches $(n=72)$ & $1.31 \pm 0.27$ & $13.5 \pm 2.8$ \\
Durum rolls $(n=4)$ & $1.29 \pm 0.27$ & $13.6 \pm 3.7$ \\
Grilled meals $(n=57)$ & $1.20 \pm 0.49$ & $10.9 \pm 5.5$ \\
All $(n=189)$ & $1.36 \pm 0.51$ & $13.1 \pm 4.4$ \\
\hline
\end{tabular}


Table 4. Salt content in selected types of fast food (mean \pm SD)

\begin{tabular}{|c|c|c|c|c|}
\hline & $\begin{array}{l}\text { Food amount } \\
\text { (g per portion) }\end{array}$ & $\begin{array}{l}\text { Energy content per portion } \\
\qquad(\mathrm{kJ} \text { per portion) }\end{array}$ & $\begin{array}{l}\text { Salt content per portion } \\
\text { (g per portion) }\end{array}$ & $\begin{array}{l}\text { Salt content per } \\
10 \mathrm{MJ}(\mathrm{g} \text { per } 10 \mathrm{MJ})\end{array}$ \\
\hline Burger with meat, small $(n=6)$ & $173 \pm 67$ & $1,558 \pm 406$ & $1.8 \pm 0.4$ & $11.8 \pm 1.0$ \\
\hline Burger with meat, big $(n=6)$ & $342 \pm 64$ & $3,363 \pm 752$ & $3.4 \pm 1.2$ & $10.0 \pm 3.0$ \\
\hline Burger with meat/bacon/cheese $(n=4)$ & $382 \pm 40$ & $3,768 \pm 473$ & $4.9 \pm 1.1$ & $12.9 \pm 1.8$ \\
\hline Sandwich with chicken/bacon $(n=4)$ & $304 \pm 37$ & $2,680 \pm 524$ & $4.4 \pm 1.5$ & $16.0 \pm 2.8$ \\
\hline Sandwich with egg/shrimps $(n=4)$ & $280 \pm 20$ & $2,213 \pm 82$ & $3.1 \pm 0.7$ & $14.0 \pm 2.5$ \\
\hline Sandwich with kebab $(n=4)$ & $300 \pm 28$ & $2,750 \pm 287$ & $3.5 \pm 0.2$ & $12.8 \pm 1.4$ \\
\hline Pitas with kebab $(n=4)$ & $274 \pm 51$ & $1,963 \pm 217$ & $2.4 \pm 0.5$ & $12.0 \pm 1.5$ \\
\hline Pitas with chicken $(n=4)$ & $383 \pm 163$ & $2,805 \pm 1,532$ & $3.8 \pm 2.4$ & $13.8 \pm 3.6$ \\
\hline Pitas with salad $(n=4)$ & $262 \pm 38$ & $1,690 \pm 297$ & $1.6 \pm 0.4$ & $9.5 \pm 2.2$ \\
\hline French hot dog $(n=4)$ & $156 \pm 9$ & $1,875 \pm 182$ & $2.9 \pm 0.1$ & $15.6 \pm 1.6$ \\
\hline Hot dog $(n=4)$ & $184 \pm 36$ & $1,987 \pm 332$ & $2.9 \pm 0.7$ & $14.7 \pm 1.9$ \\
\hline Pizza pepperoni $(n=4)$ & $4 \mid 4 \pm 40$ & $5,608 \pm 662$ & $8.2 \pm 2.2$ & $15.0 \pm 5.0$ \\
\hline Pizza, vegetarian $(n=4)$ & $548 \pm 112$ & $5,223 \pm 1,489$ & $7.6 \pm 2.6$ & $14.7 \pm 4.7$ \\
\hline Pizza with meat/fish $(n=4)$ & $586 \pm 106$ & $5,683 \pm 731$ & $11.3 \pm 4.3$ & $19.5 \pm 6.6$ \\
\hline
\end{tabular}

5-6 g per day. The extrapolation assumes that the salt content per MJ is similar in all meals consumed during the day. This does not have to be true. Beverages, for instance, contain very little salt. The hot meals had the highest salt content, whereas salad had the lowest. Thus, if a hot meal is consumed both as lunch and dinner then the daily salt intake is expected to be even higher than the extrapolated mean intake of $14.6 \mathrm{~g}$ per day and the opposite must be true if mainly salad meals are consumed. The salt content in breakfasts have not been investigated, but is expected to vary according to the kind of food eaten; some breakfast cereals, e.g. corn flakes have a high salt content whereas others, e.g. oat have a very low content (13).
A limit at $1.0 \mathrm{~g}$ salt per $100 \mathrm{~g}$ has been set for the use of Keyhole labeling (a label which emphasizes the better choice within a food group) for ready-prepared dishes in Denmark (17). More than half (61\%) of the worksite canteen meals was at or below this limit. However, the limit seems rather high as one meal with a content of $1.0 \mathrm{~g}$ salt per $100 \mathrm{~g}$ can provide an amount close to the daily recommended intake. Expressed per energy unit, the content of salt is very high in the worksite canteen meals.

In order to reach the recommendation of salt intake, salt intake from all sources must be reduced including meals consumed within and outside the homes. To our knowledge, no intervention studies with focus on salt

Table 5. Salt content in fast food meals

\begin{tabular}{|c|c|c|c|c|}
\hline & $\begin{array}{l}\text { Food amount } \\
\text { (g per meal) }\end{array}$ & $\begin{array}{l}\text { Energy content per } \\
\text { meal ( } k J \text { per meal) }\end{array}$ & $\begin{array}{l}\text { Salt content per } \\
\text { meal ( } g \text { per meal) }\end{array}$ & $\begin{array}{l}\text { Salt content per } \\
10 \mathrm{MJ}(\mathrm{g} \text { per } 10 \mathrm{MJ})\end{array}$ \\
\hline Sausage with bread, ketchup, mustard, and remoulade & 233 & 2,473 & 4.7 & 19 \\
\hline $\begin{array}{l}\text { Sausage with bacon, bread, ketchup, mustard, and } \\
\text { remoulade }\end{array}$ & 296 & 3,184 & 6.3 & 20 \\
\hline $\begin{array}{l}\text { Fillet of fish, two pieces with chips, remoulade, and } \\
\text { lemon }\end{array}$ & 450 & 5,687 & 4.4 & 7.7 \\
\hline $\begin{array}{l}\text { Spring rolls with soy sauce, mixed salad, creme fraiche } \\
\text { dressing }\end{array}$ & 366 & 3,083 & 6.5 & 21 \\
\hline Kebab mix with raw onions, dressing, and mixed salad & 450 & 5,598 & 5.9 & 10.5 \\
\hline $\begin{array}{l}\text { Half grilled chicken with chips, remoulade, ketchup, and } \\
\text { cucumber salad }\end{array}$ & 635 & 6,536 & 7.8 & 11.9 \\
\hline $\begin{array}{l}\text { Chicken nuggets with sweet-sour sauce, chips, bread, } \\
\text { and mixed salad }\end{array}$ & 531 & 5,098 & 9.1 & 17.9 \\
\hline
\end{tabular}


intake has been carried out in worksite canteens. A study that focused on fat and salt content in school cafeterias (18) found at follow up among the 88 participating schools that none reached the goal of less than $2.5 \mathrm{~g}$ salt in a lunch meal, although they have paid attention on several guidelines to lower salt intake (18).

No data exist for the number of persons eating a meal daily in a worksite canteen in Denmark. Fast food is eaten frequently in many countries and the frequency of fast food use has increased dramatically since the 1970s (7). In Denmark, the intake of fast food among 4-18-year old boys and girls has increased from 1995 to 2004 (19, 20 ), and the actual intake in the group 15-18-year old is a little above $100 \mathrm{~g}$ a day. The present study shows, not surprisingly, a high content of salt in fast food meals. Thus, a pizza meal, for instance, can provide up to twice the recommended daily intake.

In the USA it has been found that the intake of salt was significantly higher among individuals who eat fast food regularly than among individuals who don't eat fast food (20). Likewise, a study found that salt intake was significantly higher among young women who were classified as having a fast food eating pattern than among women classified with other eating patterns (8). In contrast, no difference in salt intake was found between a day when fast food was eaten and a day fast food was not eaten in another USA study (21). Fast food consumption has been related to higher energy intake, overweight, and poor diet quality (22), and the risk of hospital admissions for acute coronary heart disease was higher in regions with greater numbers of fast food services than in regions with few (23). The reason why fast food is regarded as unhealthy is mainly the high content of fat, trans fatty acids and energy, and the high salt content is another reason why fast food in general is an unhealthy choice.

In conclusion, the content of salt is high in both canteen meals and fast food. If the recommendation for salt intake should be reached it is necessary to lower the salt content in these meals.

\section{Conflict of interest and funding}

The authors have no conflicts of interest and did not receive any funding or benefits from industry to conduct this study.

\section{References}

1. He FJ, MacGregor GA. A comprehensive review on salt and health and current experience of worldwide salt reduction programmes. J Hum Hypertens 2009; 23: 363-84.

2. Cohen HW, Hailpern SM, Fang J, Alderman MH. Sodium intake and mortality in the NHANES II follow-up study. Am J Med 2006; 119: 275.e7-e14.
3. Joossens JV, Hill MJ, Elliott P, Stamler R, Lesaffre E, Dyer A, et al. Dietary salt, nitrate and stomach cancer mortality in 24 countries. European Cancer Prevention (ECP) and the INTERSALT Cooperative Research Group. Int J Epidemiol 1996; 25: 494-504.

4. Nordic Council of Ministers. Nordic nutrition recommendations 2004. Integrating nutrition and physical activity. Copenhagen, Denmark. Nord 2004; 13.

5. Andersen L, Rasmussen LB, Larsen EH, Jakobsen J. Intake of household salt in a Danish population. Eur J Clin Nutr 2009; 63: 598-604.

6. Bertino M, Beauchamp GK, Engelman K. Increasing dietary salt alters salt taste preference. Physiol Behav 1986; 38: 203-13.

7. French SA, Harnack L, Jeffery RW. Fast food restaurant use among women in the pound of prevention study: dietary, behavioral and demographic correlates. Int J Obes Relat Metab Disorders 2000; 24: 1353-9.

8. Haines PS, Hungerford DW, Popkin BM, Guilkey DK. Eating patterns and energy and nutrient intakes of US women. J Am Diet Assoc 1992; 92: 698-704, 707.

9. Lassen A, Hansen K, Trolle E. Comparison of buffet and a la carte serving at worksite canteens on nutrient intake and fruit and vegetable consumption. Public Health Nutr 2007; 10: 292-7.

10. Nordic Committee on Food Analysis. Ash. Gravimetric determination in foods. Method No. 128. Oslo: NKML; 1989.

11. Nordic Committee on Food Analysis. Fat. Determination in foods. Method No. 160. Oslo: NKML; 1998.

12. Nordic Committee on Food Analysis. Nitrogen. Determination in foods and feeds according to Kjeldahl. Method No. 6, 4th ed. Oslo: NMKL; 2003

13. Saxholt E, Møller A. Fødevaretabeller [Food tables], 4th ed. Copenhagen: National Food Agency of Denmark; 1996.

14. National Food Institute, Technical University of Denmark, 2009. Danish Food Composition Databank, version 7.01, released March 2009. Available from: http://www.foodcomp.dk [cited 2 March 2009].

15. Noel L, Leblanc JC, Guerin T. Determination of several elements in duplicate meals from catering establishments using closed vessel microwave digestion with inductively coupled plasma mass spectrometry detection: estimation of daily dietary intake. Food Addit Contam 2003; 20: 44-56.

16. Lachat CK, Huybregts LF, Roberfroid DA, Van CJ, Remaut-De Winter AM, Debruyne P, et al. Nutritional profile of foods offered and consumed in a Belgian university canteen. Public Health Nutr 2009; 12: 122-8.

17. Bekendtgørelse om anvendelse af Nøglehulsmærket [Notice on the use of the Keyhole symbol]. BEK nr. 456. Fødevarstyrelsen 9/6-2009.

18. Hoelscher DM, Feldman HA, Johnson CC, Lytle LA, Osganian SK, Parcel GS, et al. School-based health education programs can be maintained over time: results from the CATCH Institutionalization study. Prev Med 2004; 38: 594-606.

19. Fagt S Groth MV Andersen NL. Danskernes kostvaner 1995. Mad og måltider [Dietary habits of Danes. Foods and meals]. Fødevaredirektoratet, publikation nr. 235, 1999, Søborg, Denmark.

20. Fagt S, Christensen T, Groth MV, Biltoft-Jensen A, Matthiessen J, Trolle E. Børn og unges måltidsvaner 2000-2004 [Dietary habits of children and young people 2000-2004]. Fødevareinstituttet, Technical University of Denmark, 2007. Available from: http://www.food.dtu.dk [cited 2 April 2009].

21. Paeratakul S, Ferdinand DP, Champagne CM, Ryan DH, Bray GA. Fast-food consumption among US adults and children: 
dietary and nutrient intake profile. J Am Diet Assoc 2003; 103: $1332-8$.

22. Schroder H, Fito M, Covas MI. Association of fast food consumption with energy intake, diet quality, body mass index and the risk of obesity in a representative Mediterranean population. Br J Nutr 2007; 98: 1274-80.

23. Alter DA, Eny K. The relationship between the supply of fastfood chains and cardiovascular outcomes. Can J Public Health 2005; 96: 173-7.
*Lone Banke Rasmussen

Department of Nutrition National Food Institute

Technical University of Denmark

Mørkhøj Bygade 19

DK-2860 Søborg, Denmark

Tel: +4535887427

Fax: +4535887 II 9

Email: lbra@food.dtu.dk 